\title{
The Comparative Study of Tool Marks on Non-Ferrous Metalwork from Archaeological Contexts: Methodological Considerations, Case Studies and Experimental Archaeology
}

\author{
Birgit Bühler $^{1^{*}}$, Dávid Zsolt Schwarcz ${ }^{2}$ \\ ${ }^{1}$ Vienna Institute for Archaeological Science, University of Vienna, Franz-Klein Gasse 1, 1190 Vienna, Austria \\ ${ }^{2}$ Austrian Archaeological Institute, Austrian Academy of Sciences, Franz Klein-Gasse 1, 1190 Vienna, Austria
}

\section{ARTICLE INFO}

\section{Article history:}

Received: $9^{\text {th }}$ September 2020

Accepted: $18^{\text {th }}$ February 2021

DOI: http://dx.doi.org/10.24916/iansa.2021.1.5

\section{Key words:}

Avar archaeology

Byzantium

non-ferrous metalwork

technology transfer

experimental archaeology

\begin{abstract}
A B S T R A C T
The aim of this paper is to discuss methodological issues of comparative tool mark studies (with special attention to decorative punched motifs), using a case study on sheet-gold metalwork from the Middle and Late Avar Period ( $7^{\text {th }}-8^{\text {th }}$ centuries AD). The historical interpretation of tool marks on nonferrous metalwork ${ }^{1}$ can take place at different levels of complexity. In some cases, the identification of products from the same craftsperson is possible, via the identification of specific tools. However, when interpreting the results of comparative tool mark studies, many aspects are relevant, including individual variations in tool usage. In this context, experimental archaeology can facilitate the interpretation of tool marks, as is demonstrated in a preliminary study on two types of punches, which are common on high-quality metalwork from the Avar Period.
\end{abstract}

\section{Introduction}

The framework of technological necessities for creating a particular effect in metalworking is definable. Within this framework, in many cases, the individual metalworker has a number of choices. The technical decisions taken in each case will depend on the craftsperson's skills, personal preferences and background, on smaller-scale "workshop traditions", on larger-scale "cultural traditions", as well as on the demands of the customer regarding motifs, style, material and technique in the finished product. Hence, the technological choices made in the production process of a particular object are important evidence, which may reveal its place of production, as well as the cultural or even social background of the craftsperson and the recipient of the product in question. The aim of this paper is to give an overview of the methodology of tool mark studies on gold and silver metalwork from archaeological contexts, to demonstrate potential applications of this

*Corresponding author. E-mail: birgit.buehler@univie.ac.at approach with the help of a case study and to suggest possible directions for future interdisciplinary research, for example, using experimental archaeology. The first part of the paper (see chapter 2) discusses methodological aspects of the comparative study of tool marks on precious metalwork from archaeological contexts, including a case study from the early medieval period. The second part of the paper (see chapter 3 ) is a preliminary experimental study of several types of punching tools, which commonly occur in decorative techniques on early medieval non-ferrous metalwork: The purpose of this section is to demonstrate the potential of experimental archaeology for the interpretation of tool marks on non-ferrous metalwork from archaeological contexts.

1 The term "non-ferrous metals" encompasses all the metals and their alloys, which do not contain iron. Hence, this denomination includes precious metals (e.g. gold and silver) and non-precious metals, such as lead, tin, zinc, copper and its alloys (e.g. bronze, brass, etc.), to mention the most relevant concerning tool mark analyses on archaeological metal artefacts. 


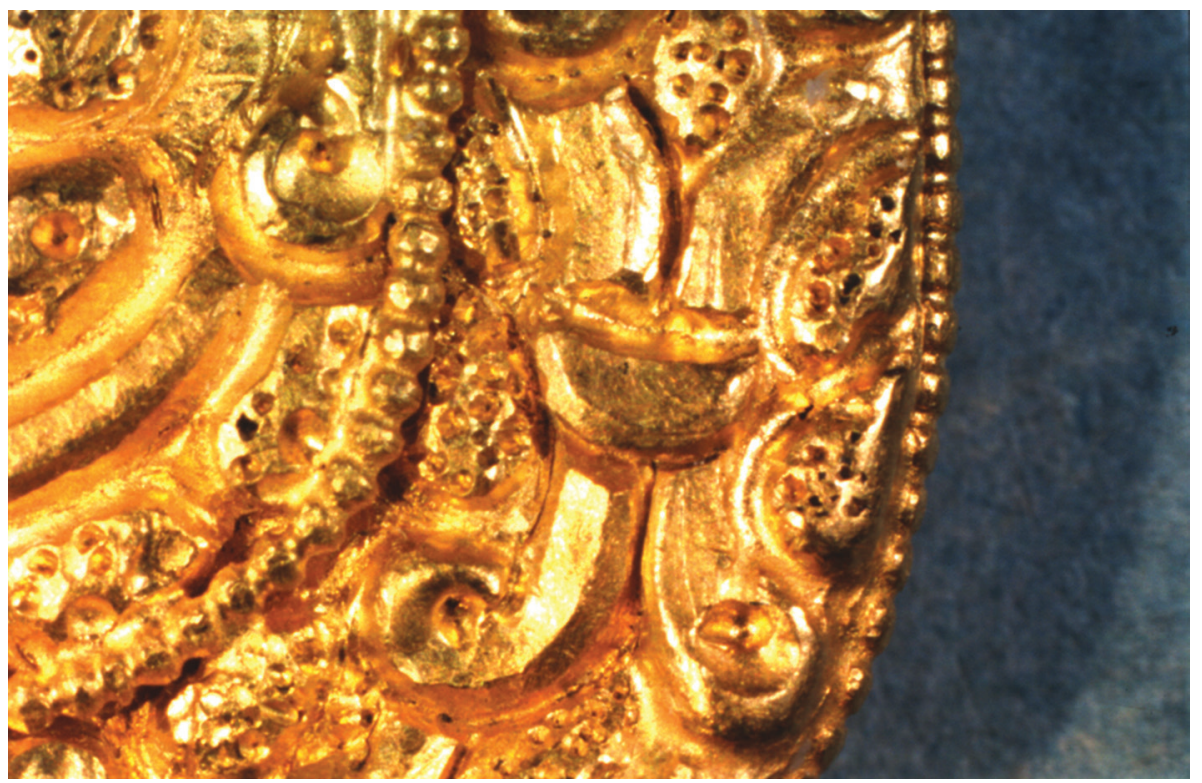

Figure 1. Gold belt-buckle from the "Brestovac Hoard" (Croatia; end of eighth - early ninth century AD). Kunsthistorisches Museum Wien, Antikensammlung, inv. no. VII B 70. Detail of sheet gold fitting: Highly stylised plant motif ("Stäbchenranke") characteristic for the Late Avar Period III in repoussé ("Treibziselieren"), worked predominantly from the front; surface of leaves decorated with "stippling punch" (Photo: B. Bühler).

\section{Tool mark studies on gold and silver metalwork from archaeological contexts}

\subsection{Methodological considerations}

The purpose of "basic tool mark studies" on precious metalwork from archaeological contexts is to identify the techniques used in manufacturing and decorating a particular artefact and to reconstruct its production process. In contrast, the aim of "comparative tool mark studies" on precious metalwork from archaeological contexts is the historical interpretation of the technological evidence. Hence, "basic tool mark studies" constitute a pre-requisite for further, historical interpretation of the evidence, which also requires the inclusion of additional criteria, derived from other, related metalwork and the archaeological context ("comparative tool mark studies"). As will be illustrated below, in a case study, the process of historical interpretation of tool marks can take place at different levels. Starting at the lowest, most specific level, this process can involve the identification of individual tools, followed by the identification of specific types of tool, by technical preferences and idiosyncrasies of individual metalworkers and progressing to the higher-level aspects, such as the identification of metalworking traditions characteristic for individual workshops, as well as to larger-scale, local or regional metalworking traditions.

Therefore, comparative tool mark studies may permit researchers to identify artefacts produced by the same

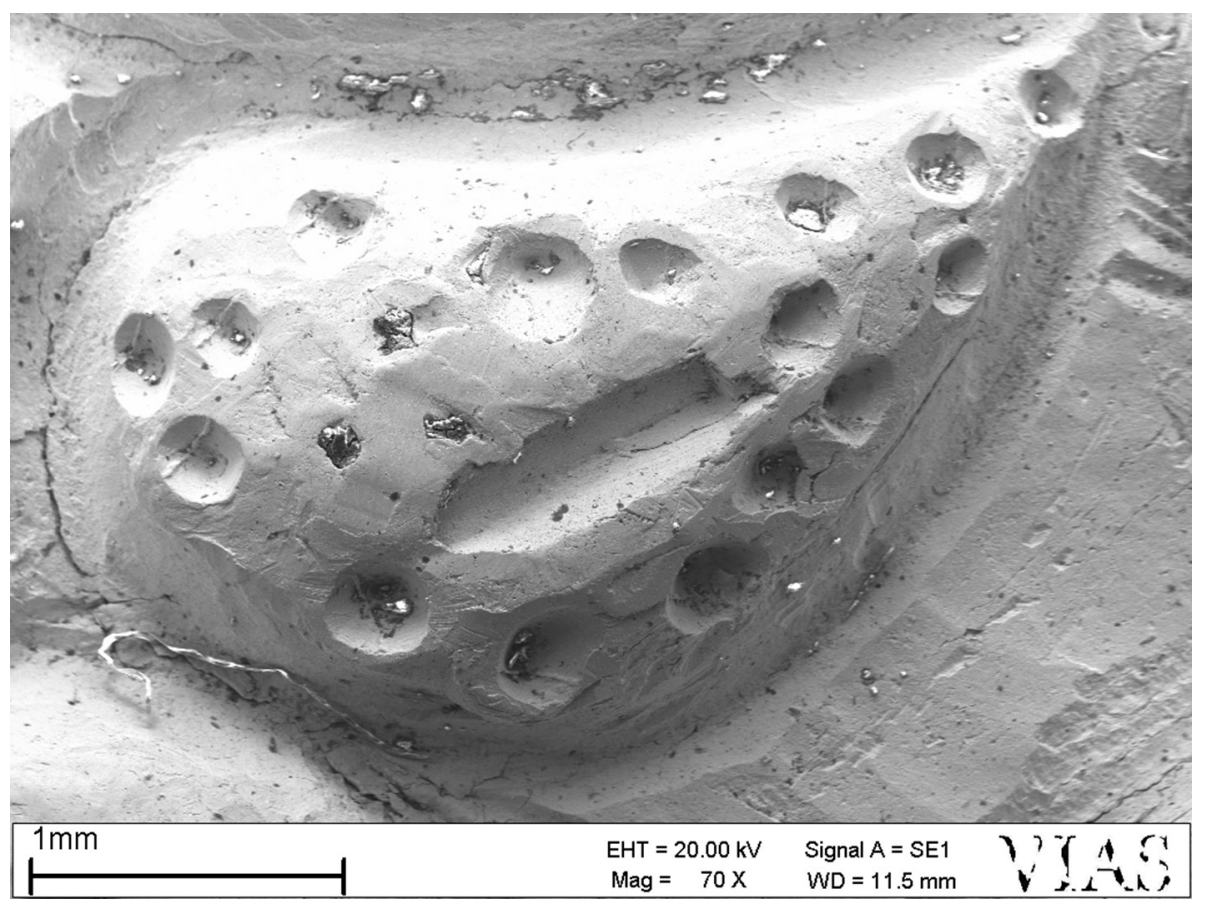

Figure 2. Gold belt-buckle from the "Brestovac Hoard" (Croatia; end of eighth - early ninth century AD). Kunsthistorisches Museum Wien, Antikensammlung, inv. no. VII B 70. SEM-Detail of sheet gold fitting: Repoussé ("Treibziselieren"), worked predominantly from the front; surface of leaf decorated with "stippling punch" (Photo: M. Mehofer, VIAS) 
Figure 3. Gold bowl number 13 from the "Nagyszentmiklós (Sânnicolau Mare) Hoard" (Romania; end of eighth - early ninth century AD). Kunsthistorisches Museum Wien, Antikensammlung, inv. no. VII B 10. Detail of stylised plant ornament ("Stäbchenranke") in repoussé, including leaves with "stippled surface" and background filled with ring-shaped punchmarks (Photo: Kunsthistorisches Museum Wien).
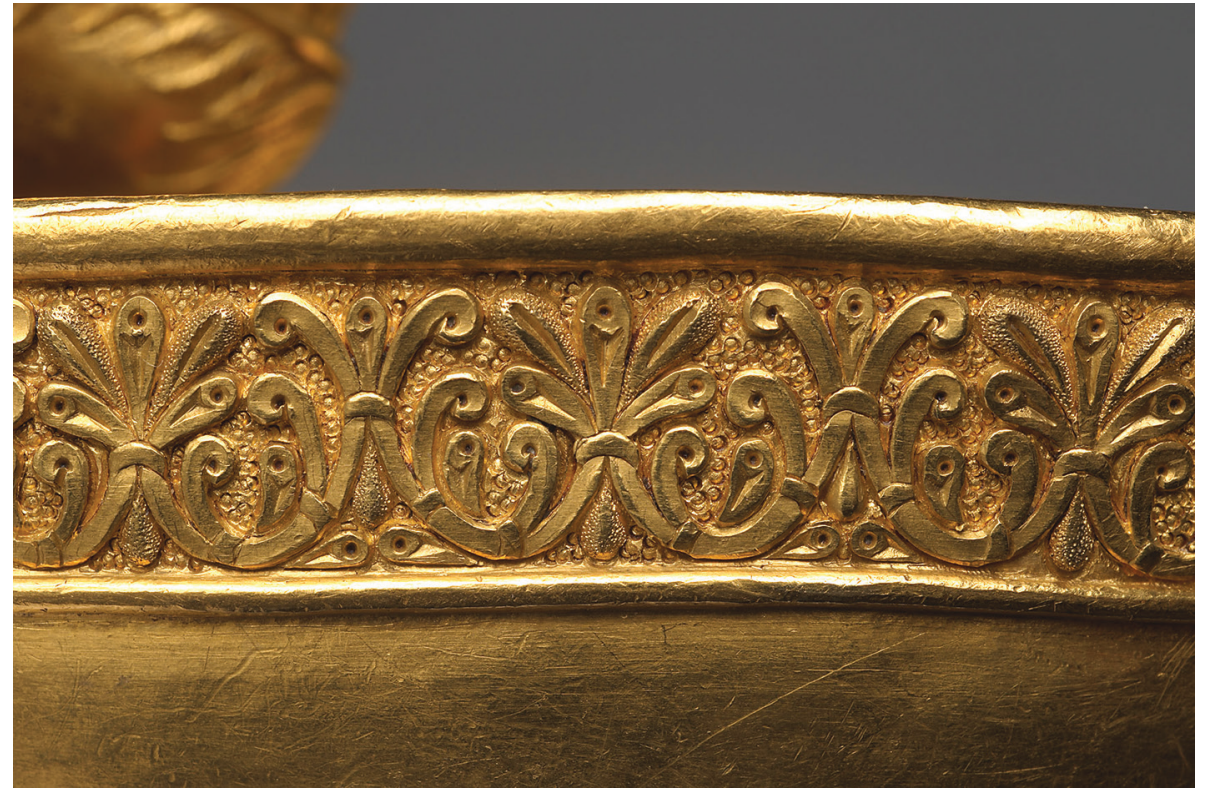

craftsperson: The best way of verifying such an assumption is to demonstrate the use of identical tools in the production process of two or more particular metal products. The prerequisite for this, however, is the identification of individual tools on the metal objects in question. Characteristic irregularities on the surface of a tool's working-edge (see, for example, Figure 4, below) can facilitate the identification of specific, individual metalworking tools. In the absence of such typical faults, exact measurements of the dimensions of the tool-marks may assist in identifying a specific tool. Ideally, a Scanning Electron Microscope (SEM) is available for precise measurements of tool mark dimensions, although a variety of other measurement options exists (see other comparative tool mark studies focusing on punching especially as a decorative technique, Larsen, 1987; Mortimer, Stoney, 1997 and Dal, 2017, pp.131-144).

However, when interpreting the results of comparative tool mark studies, several aspects are relevant: Firstly, the surface of a tool's working-edge may change with time. This could either be due to the natural process of use-wear or to intentional re-shaping by a craftsperson. Secondly, tool marks originating from the same tool may vary in size and appearance (for examples, see chapter 2.2), due to variations in the orientation of the tool to the metal surface and because of variations in pressure when using the tool. As will be demonstrated in chapter 3, experimental archaeology can assist in the interpretation of tool marks on non-ferrous metalwork from archaeological contexts. Thirdly, traces of

Figure 4. Gold bowl number 13 from the "Nagyszentmiklós (Sânnicolau Mare) Hoard" (Romania; end of eighth - early ninth century AD). Kunsthistorisches Museum Wien, Antikensammlung, inv. no. VII B 10. SEM-Detail: Tool marks of "stippling punch" with characteristic irregularity (Photo: M. Mehofer, VIAS).

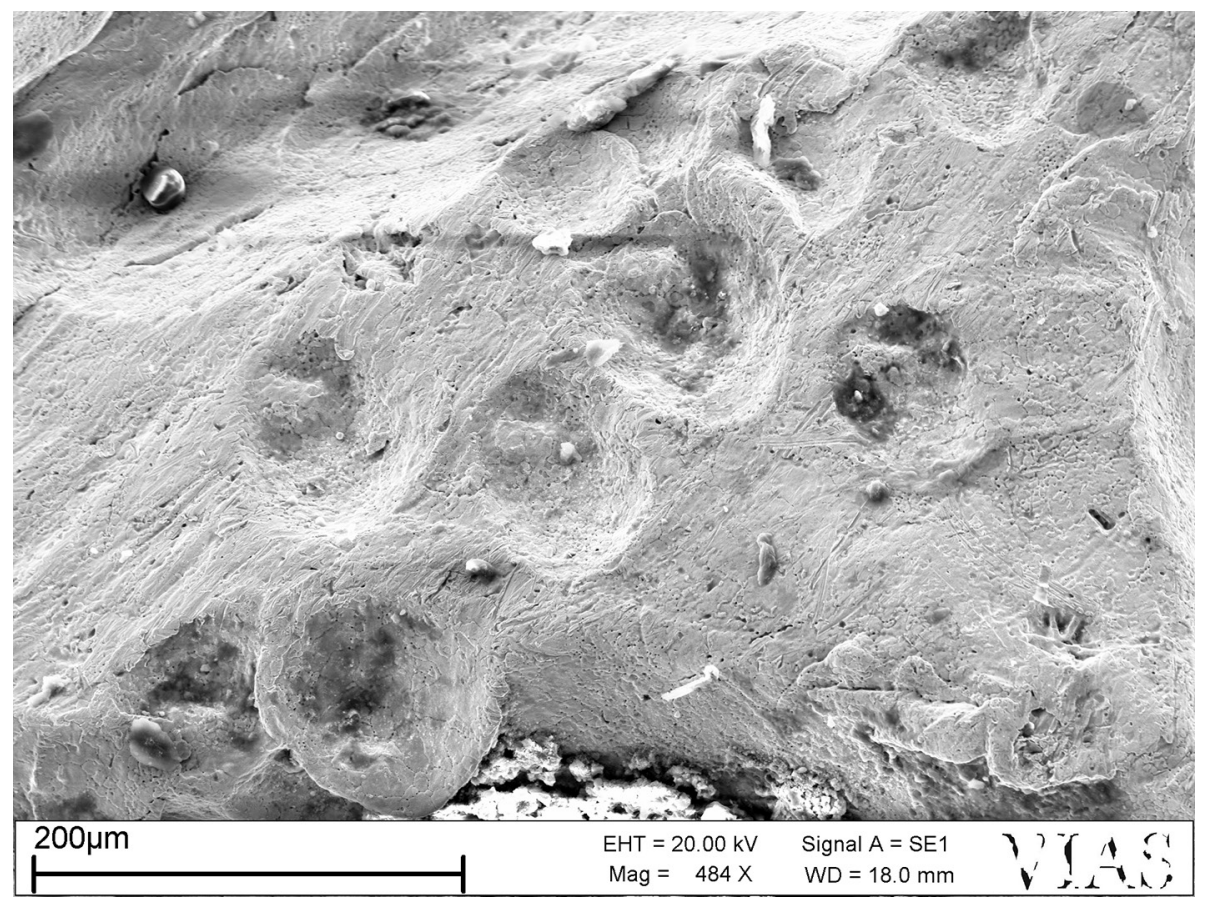



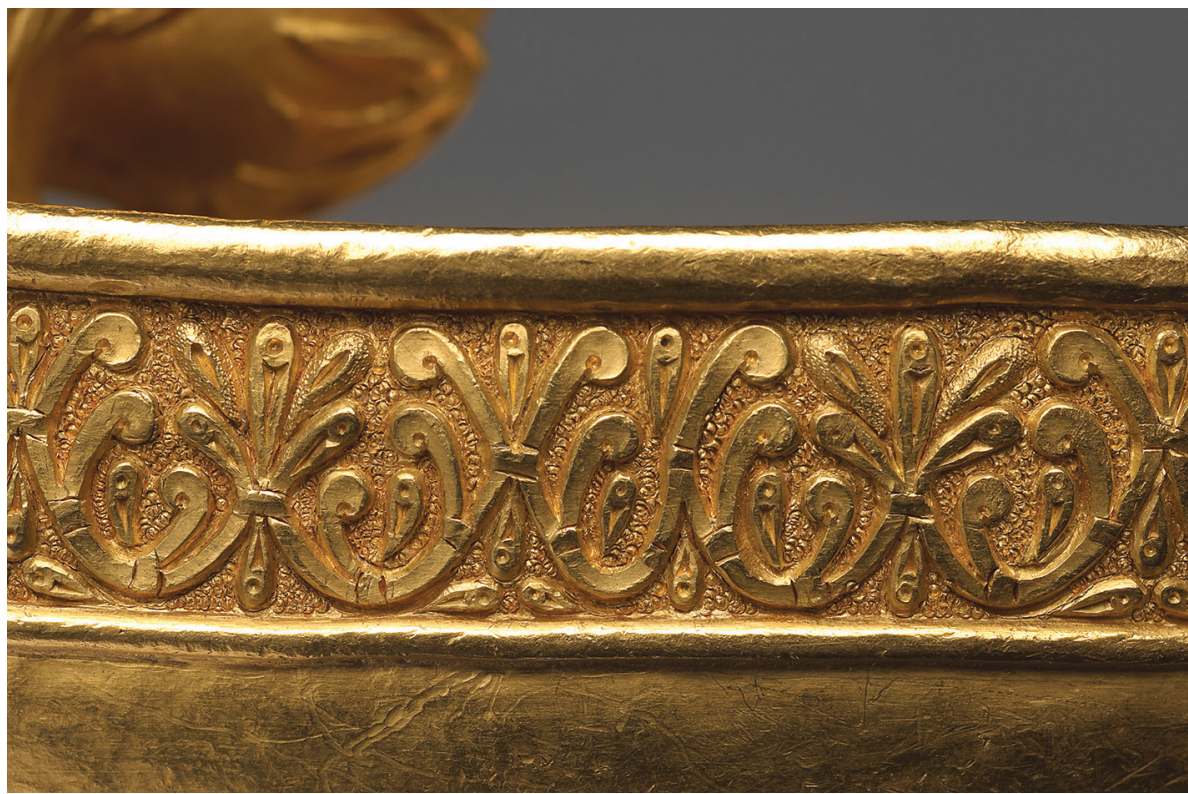

Figure 5. Gold bowl number 14 from the "Nagyszentmiklós (Sânnicolau Mare) Hoard" (Romania; end of eighth - early ninth century AD). Kunsthistorisches Museum Wien, Antikensammlung, inv. no. VII B 11. Detail of stylised plant ornament ("Stäbchenranke") in repoussé, including leaves with "stippled surface" and background filled with ring-shaped punch-marks; mistake in design of plant ornament, reflecting a difference in quality to number 13 (Photo: Kunsthistorisches Museum Wien). wear on the surface of a metal object may alter the original shape and size of tool marks.

\subsection{Case study: Interpreting decorative techniques on sheet-gold metalwork from the Middle and Late Avar Period $\left(7^{\text {th }}-8^{\text {th }}\right.$ centuries AD)}

Interdisciplinary research on non-ferrous metalwork can be helpful in identifying cultural traditions in archaeological contexts. For example, there is ample evidence for a close connection between "Byzantine" and "Avar" culture in the $7^{\text {th }}$ and $8^{\text {th }}$ centuries AD. However, the mechanisms of cultural and technological transfer, as well as the regions where such transfer processes may have taken place, are still subject to debate. Comparative tool mark studies on precious metalwork could contribute to resolving these questions, in particular in conjunction with other criteria derived from archaeological research. In this context, specific variations in decorative techniques for working precious metals are relevant: True repoussé (= three-dimensional modelling of sheet metal using individual tools, such as several different types of punches; "Treibziseliertechnik") was an uncommon technique in the Avar realm. However, it occurs within Avar territory on a number of high-quality items of metalwork (mainly gold objects; see Figures 1-5), which may be associated - for typological, stylistic and/ or technological reasons - with "Byzantine" culture. In the Early and Middle Avar Period ( $7^{\text {th }}$ century), the standard production method for gold-, silver- and copper-alloy jewellery and dress ornaments was pressing pieces of sheet metal over positive models ("formers"). In the Late Avar Period ( $8^{\text {th }}$ century), on the other hand, the dominant technique for manufacturing non-ferrous jewellery and dress ornaments was the casting process. However, in the Mediterranean region, true repoussé ("Treibziseliertechnik") was a common technique for producing three-dimensional decoration on highquality sheet metal (gold, silver and copper alloy) objects. Although the import of top-quality gold metalwork with repoussé ornament from the Byzantine Empire is a feasible interpretation, an alternative hypothesis is that they are in fact products of "Byzantine" type, produced in workshops on the periphery of the Byzantine Empire with technical expertise from Byzantium. In any case, it seems feasible to associate the occurrence of these specific decorative techniques on metalwork found on Avar territory with "Byzantine metalworking traditions", although the specific workshops cannot yet be located (Bühler, 2014).

This case study summarizes the results of comparative tool mark studies on high-quality sheet gold metalwork from the Middle and Late Avar Period ( $7^{\text {th }}-8^{\text {th }}$ centuries AD), by focusing on two key finds from this period, both of which are in the collection of the Kunsthistorisches Museum Wien, Austria (Antikensammlung). Firstly, there are the 23 gold vessels from the "Nagyszentmiklós (Sânnicolau Mare) Treasure" (for an overview of archaeological research, see Bálint, 2010; for the results of archaeometallurgical research, see: Bühler, Freiberger, 2018), found in presentday Romania in 1799. Secondly, there are four gold belt ornaments from the so-called "Brestovac Hoard", found in present-day Croatia in 1821. The plant ornament on the youngest group of gold vessels (seven bowls with "Stäbchenrankenzier" = Nos. 13-16 and 19-21; late $8^{\text {th }}$ century AD) from the "Nagyszentmiklós (Sânnicolau Mare) Treasure" is closely related to the decoration of the gold belt fittings from Brestovac (Bühler, 2014). Similarly, comparative tool mark studies have revealed that the repoussé work on the group of gold vessels with "Stäbchenrankenzier" from Nagyszentmiklós (Figures 3-5) and on the gold belt fittings from Brestovac (Figures 1-2) is strikingly similar (Bühler, 2014). In particular, the process of modelling the three-dimensional plant ornament from sheet gold was almost identical, although in terms of quality, the repoussé ornament on the gold vessels is of a higher standard than on the gold belt-fittings. For example, the tool marks on the vessels represent a larger variety of different tool types, 
as well as finer tools, than the tool marks detected on the belt ornaments. The increased number of tools used on the vessels could be explained by the difference in the size of the objects under discussion. Hence, either limited or extended possibilities are available for surface decoration, depending on the dimensions of the given item. However, both on the vessels and on the belt-fittings, the repoussé ornament is characterised by a remarkably three-dimensional relief, created mainly by working the sheet gold from the front (i.e. by pushing down the background of the ornament). It is not surprising that the production of three-dimensional relief ornament on sheet-gold vessels occurred predominantly by working from the front (or outside) of the vessel, because this is advantageous from a technical point of view. In the case of the belt fittings, however, working from the front is an unusual technique, for which technical advantages do not suffice as an explanation. This observation, together with other technical similarities, could support the hypothesis that the production of gold vessels and gold belt fittings with "Stäbchenrankenzier" may have taken place in closelyrelated workshops with similar metalworking traditions perhaps even in the same workshop (Bühler, 2014). However, there was no evidence for the use of specific, identical tools on both the vessels and the belt fittings. Clearly, on the vessels much finer tools were used, and more skilfully, than on the belt fittings.

The use of "stippling punches" (see Figures 1-5) within this typological group (= sheet-gold objects with "Stäbchenrankenzier"; see Bühler, 2014) provides evidence for closely-related workshop traditions, but distinct variations in skill and in the quality of metalworking technology. "Stippling punches" served the purpose of creating a finelytextured surface, which occurs especially on decorative elements of the stylised plant ornament characteristic for this group. The shape of the tool marks suggests that the "stippling punches" used within this group of Late Avar metalwork were all very fine tools with a conical working edge. Although the same type of tool - a fine "stippling punch" - was used for creating the characteristic, finely "stippled" surface on both the plant and animal ornament of all seven bowls with "Stäbchenrankenzier" (Numbers 13-16 and 19-21) from the "Nagyszentmiklós (Sânnicolau Mare) Treasure", different tools were used to decorate each of these vessels. This is clear from the dimensions of the tool marks of the "stippling tools", which were obtained from measurements of the SEM ${ }^{2}$ images: The finest "stippling punch" was used on bowl number 13, with tool marks of only $0.07-0.08 \mathrm{~mm}$ in diameter. The specific tool used on this vessel has a characteristic irregularity on the working edge, which facilitates its identification (see Figure 4). In contrast, the diameter of the tool marks of the stippling punches on all the other six vessels is larger. This includes

2 All SEM research on archaeological metalwork mentioned in this paper was carried out on a Zeiss EVO 60 XVP Scanning Electron Microscope at Vienna Institute for Archaeological Science (supported by the Austrian Research Fund as part of a research project on the Nagyszentmiklós Treasure, 2004-2007). the relevant tool marks (diameter $=0.16-0.21 \mathrm{~mm}$ ) on bowl number 14, which is similar to number 13 regarding a number of formal, stylistic and technological aspects, but of slightly lower quality in several aspects (Figures 3-5). This provides support for the hypothesis that the pair of bowls number 13 and 14 (Figures 3-5) was produced by different metalworkers, but perhaps within one workshop or associated workshops, with similar metalworking and cultural traditions (see Bühler, Freiberger, 2018).

In addition, the results of comparative tool mark studies show that the diameter of the stippling punch marks on the other five vessels of this group are in a similar range as those on number 14. "Stippling tool" marks of this type occur on number 21 (diameter $=0.11-0.20 \mathrm{~mm})$, number $19($ diameter $=0.13-0.22 \mathrm{~mm})$, number $20($ diameter $=0.12-0.19 \mathrm{~mm})$, number 16 (diameter $=0.15-0.28 \mathrm{~mm}$ ) and number 15 (diameter $=0.16-0.26 \mathrm{~mm}$ ). From this evidence, it is feasible to conclude that "stippling tools" of similar fineness were applied to six out of the seven gold vessels within this typological group. However, in this case, due to the absence of characteristic faults, it is impossible to identify specific tools. Hence, it is possible that more than one tool of this type was used on a given vessel. Similarly, in this case, it is impossible to verify the use of identical tools on two or more of the gold vessels within this group. For example, for the pair of bowls numbers 15 and 16, in this case, we can only conclude that "stippling tools" of the same type and very similar diameter were used - thus suggesting (possible) production in the same workshop. The problem of "normal" variation in the diameter of tool marks produced with the same tool - which is apparent in the considerable variation in diameter regarding the tool marks cited above - is addressed by experimental research (see chapter 3). "Stippling" as a decorative technique for sheet-gold metalwork is quite common in "Italo-Byzantine" precious metalwork from the $7^{\text {th }}$ century, decorated with half-palmettes and other types of stylised plant ornament (Ricci, 2012). This provides support for the hypothesis that "Italo-Byzantine" goldsmith's workshops may have represented a major factor in the process of transmitting ideas, motifs and techniques from the Mediterranean region to the Avar realm in the Carpathian Basin (Bálint, 2010; Bühler, 2014). For example, "Italo-Byzantine" metalworking traditions may have played a major role in the production of high quality, sheet-gold repoussé with "Stäbchenrankenzier", as discussed above.

Significantly, the evidence for a second decorative technique common in Avar metalwork - filling the background of chased or engraved ornament with ringshaped punch-marks (Figures 6-7) - appears to point in the same direction (Bühler, 2014), which demonstrates that comparative tool mark studies may be helpful in identifying the process of transmission of metalworking traditions. On Avar territory, the decorative technique with ring-punched background first occurs in the Middle Avar Period (middle to late $7^{\text {th }}$ century AD) and is most common towards the end of the Late Avar Period (late $8^{\text {th }}$ century AD), especially in conjunction with different types of plant ornament (Bühler, 

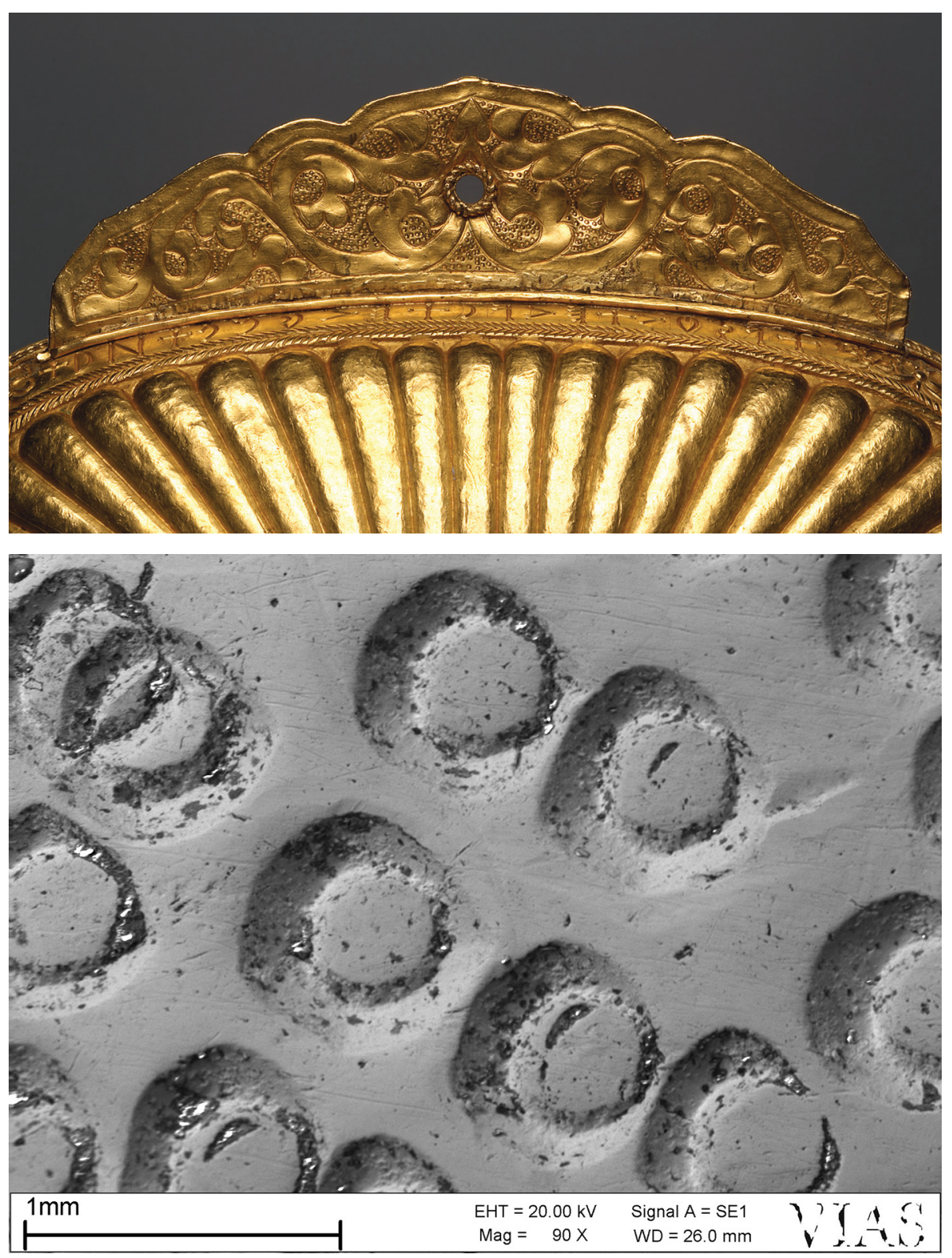

Figure 6. Gold bowl number 8 from the "Nagyszentmiklós (Sânnicolau Mare) Hoard" (Romania; eighth century AD). Kunsthistorisches Museum Wien, Antikensammlung, inv. no. VII B 4. Detail of handle: Plant ornament with chased contours and background filled with ring-shaped punch-marks (Photo: Kunsthistorisches Museum Wien).
Figure 7. Gold bowl number 8 from the "Nagyszentmiklós (Sânnicolau Mare) Hoard" (Romania; eighth century AD). Kunsthistorisches Museum Wien, Antikensammlung, inv. no. VII B 4. SEMDetail: Ring-shaped punch-marks of characteristic shape (Photo: M. Mehofer; VIAS).
2014). This decorative technique is also, for example, common on belt buckles of Byzantine type with U-shaped fittings from the $7^{\text {th }}-8^{\text {th }}$ century AD. Furthermore, the fact that this decorative technique occurs on the reverse side of a $6^{\text {th }}-7^{\text {th }}$ century AD gold cross reliquary from Monza (Italy; see Bálint, 2010) may suggest that filling the background of linear decoration, especially plant ornament, could be characteristic for Italian precious metalwork production in "Late Antique cultural tradition", but still operating in the $7^{\text {th }}$ century AD. Hence, the evidence regarding this decorative technique appears to support the hypothesis that "Italo-Byzantine" goldsmith workshops were crucial in the process of transmitting metalworking techniques, but also motifs and artistic conventions from the Mediterranean region to the Avar realm in the Carpathian Basin. In the "Nagyszentmiklós Treasure", which could represent the highest level of Avar non-ferrous metalwork in the $7^{\text {th }}-8^{\text {th }}$ century AD (Bálint, 2010; Bühler, Freiberger, 2018), plant ornament with chased or engraved contours and the background filled with ring punches occurs on four vessels - three jugs (numbers 3, 6, 7) and one bowl (number 8); see Figures 6 and 7. On three of these gold vessels, the diameter of the tool marks recorded in the SEM is within a similar range: On bowl number 8 , the diameter of ring-shaped punch-marks was $0.63 \mathrm{~mm}$ to $0.77 \mathrm{~mm}$, on jug number 7 it was $0.55 \mathrm{~mm}$ to $0.77 \mathrm{~mm}$ and on jug number 3 , the diameter was $0.52 \mathrm{~mm}$ to $0.70 \mathrm{~mm}$. The dimensions of the tool marks are sufficiently similar to suggest that they could have been produced using the same ring punch. In particular, the shape of the ring-shaped punch-marks on vessels numbers 7 and 8 is strikingly similar, suggesting that the same tool may indeed have been used when decorating these two vessels (Figure 7). The ornament with ring-shaped punch-marks on these three vessels is also linked by the fact that there is no overlap of the punch-marks (as is the case on jug number 6 , for example): On vessels numbers 3,7 and 8 , there is 
a considerable distance between the ring-shaped punchmarks, which constitute the background of the linear plant ornament. This could be due to the metalworking traditions of a particular workshop or to the preferences of a given craftsperson. In addition, on several other gold vessels from the "Nagyszentmiklós Treasure", the background of plant ornament in relief (repoussé) was also covered with ringshaped punch-marks. This includes repoussé scroll ornament on jug number 2 (diameter of ring-shaped punch-marks = $0.83 \mathrm{~mm}$ to $0.93 \mathrm{~mm}$ ) and repoussé stylized plant ornament on three bowls from the "Stäbchenranke" group. These are the pair of bowls number 13 (diameter of ring-shaped punchmarks $=0.40 \mathrm{~mm}$ to $0.52 \mathrm{~mm}$ ) and number 14 (diameter of ring-shaped punch-marks $=0.40 \mathrm{~mm}$ to $0.47 \mathrm{~mm}$ ), as well as bowl number 21 (diameter of ring-shaped punch-marks $=0.31 \mathrm{~mm}$ to $0.39 \mathrm{~mm}$ ). It must be noted that the diameter of the ring-punch marks suggests that different tools (one or perhaps several per vessel) were used on the different vessels with this type of decoration. For numbers 13 and 14, use of the same ring-punch is possible, but cannot be verified with any degree of certainty (see Figures 3 and 5). On all these vessels, there is a noticeable overlap of the ring-shaped tool-marks, which contrasts with the background of the linear ornament on vessels number 3, 7 and 8. Again, this could be interpreted either as the preferences of individual metalworkers or workshops, or even as larger-scale "metalworking traditions".

\section{Experimental tool mark studies - a preliminary case study focusing on ring punches and stippling punches}

\subsection{Introduction}

Punching is a non-cutting, cold-working decorative technique for non-ferrous metalwork, performed by tapping various small "rod-shaped" iron pressure tools (= "punches") with a hammer to create geometric and ornamental decorations on a metal surface. The punches have working edges of different shapes and sizes with the required motive (Armbruster, 2000, pp.56-58). Accordingly, there are a variety of punch types with pointed, flat, round or hollow heads in circular, rectangular, triangular and a variety of other shapes; those with a pre-prepared motive (e.g. figural, floral or a combination of geometrical shapes) are also called stamps or patterned punches (Brepohl, 1978, pp.230-231, cf. Dal, 2017, pp.132-134). Hence, punching permits the creation of diverse repetitive patterns based on dots, circles or rings, as well as convex and concave hemispheres. In addition, various types of punches are crucial for techniques aimed at raising and shaping sheet metalwork (for example, repoussé, see chapter 2, above and Bühler, 1998-1999, pp.430-433). However, this experimental study focuses exclusively on the punching techniques applied to the front side of the metal surface, in order to compile decorative repetitive patterns. Several factors influence the negative imprint of the punches' working edge and these are relevant in the examination of such tool marks (see chapter 2, above). The pressed motives, even if they derive from the same tool, may vary greatly depending on the following circumstances:

1. The hardness of the metal alloy to be decorated.

2. The force of hammer strike applied to the punch.

3. If annealing and intermediate annealing processes have been carried out.

4. The operating angle of the punch.

5. The surface geometry of the area to be processed.

All these issues affect the appearance of the punch-marks, individually as well as in combination. The hardness of the metal alloy and the applied force define the recess and contours or even the basic shape of the motive, but these could also affect the size of the punched decoration mainly on a microscopic level. These effects are enhanced if the metal is not recrystallized before the metalworking process or if the piece is not annealed (several times) during the execution of the given decoration technique. Recrystallization is essential if pressing techniques are applied. Due to simultaneous displacement and compression of the metal sheet, the crystalline structure of the alloy is deformed and the accumulated tension significantly decreases the malleability of the material (Scott, 1991, pp.3-7). This problem can be resolved by heating the product to an appropriate temperature (for copper alloys: $500-800^{\circ} \mathrm{C}$, according to Scott, 1991, p.7) to induce the recrystallization of the grain structure, thus restoring its malleability.

The force of the hammer strike on the punching tool defines the depth and even the size of the punched motive, if the punching tool has a conical or domed head. The deeper the head of the punch enters the metal, the larger the size of the tool-mark. Figure 8.2 illustrates a ring-shaped punching tool
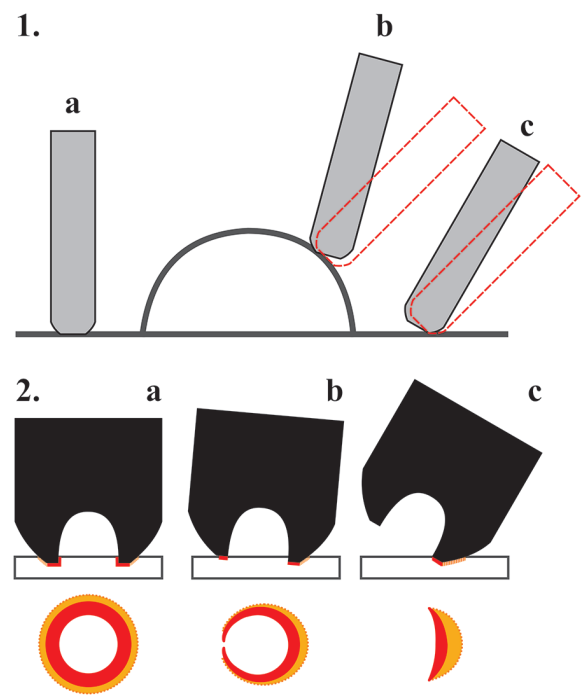

Figure 8. Schematic illustration of punching technique. 1: Punches held in a) 90 degrees on flat, b) 90-120 degrees on domed, and c) 45-60 degrees on flat, metal surface. 2: Variations of tool marks left by the same punch depending on the operating angle and the force of hammer blow. Red line: the actual working edges of the tool (leaving sharp marks); Orange interrupted line: the external convex side of the punch's head (leaving blunt marks). Illustration by D. Schwarcz. 
in practical use, showing that the tip of the punch (= "working edge") is responsible for forming the (constant) ring pattern with sharp edges (Figure 8.2 - red markings). At the same time, the slightly curved side of the punch's head determines the final size of the ring (including a concave "rim"; see Figure 8.2 - yellow and orange markings) depending upon how deep the head enters the surface of the metal. Basic sharp-edged ring patterns without a rim would appear either if the head of the punch has straight or slightly concave sides or if the metal being worked on became rigid (Figure 14.5); additionally, the lack of a solid support (e.g. a backing block) could contribute to the formation of such a pattern.

The operating angle of the punch, described as the angle between the punching tool and the (horizontal) surface of the work piece, greatly influences the shape of the punched motive. In a normal operating state, the punch should be held perpendicular to the surface. Even the slightest alteration of the angle could result in a different pattern (e.g. in an interrupted circle instead of a full circle, $c f$. Figures 8.1-2), especially if any of the previous factors coincide. The distortion of the original motive could be enhanced if the surface is threedimensional (e.g. domed), since the working edge could hardly be placed on the surface and be at the correct angle to the surface.

Due to the issues concerning the variability of patterns created by the same tool, specialists of non-ferrous metalworking techniques give special attention to reoccurring irregularities of punched marks (Armbruster, 2000, p.116). A characteristic flaw appearing on several punched decorations (see also chapter 2, above) suggests that those motives were created by the same tool, which either had a fault in its original design or its working edges had started to deteriorate (Larsen, 1987, pp.404-405, Mortimer, Stoney, 1997, p.121).

\subsection{Experimental research on punched decoration}

The purpose of this preliminary experimental research, using different punches under controlled conditions, was to expand our practical knowledge on punched decoration (see the tools and the experimental sample in Figure 9). Our main aim was to understand how the factors described above (see chapter 3.1) may influence the tool marks left on the surface of metal objects and to gain comparative visual data for future technological analyses. Based on the briefly outlined technical process of punching, with particular attention to the difficulties of tool mark identification, the following questions were of primary interest.

- To what extent does the profile and especially the side of the punching tool's working edge influence the tool marks?

- To what degree does the shape and size of the tool marks change depending on the operating angle?

- Are there differences between the tool marks created by the same tool?

Firstly, sample 1, a small rectangular metal strip ${ }^{3}$, was

\footnotetext{
Measurements of the metal strip: Length $\times$ Width $6.050215 \times 1.53 \mathrm{~cm}$, Thickness $0.06 \mathrm{~cm}$. Abbreviations used in the following: L. = length; $\mathrm{W} .=$ width THK. $=$ thickness; DIA.$=$ diameter.
}

1.
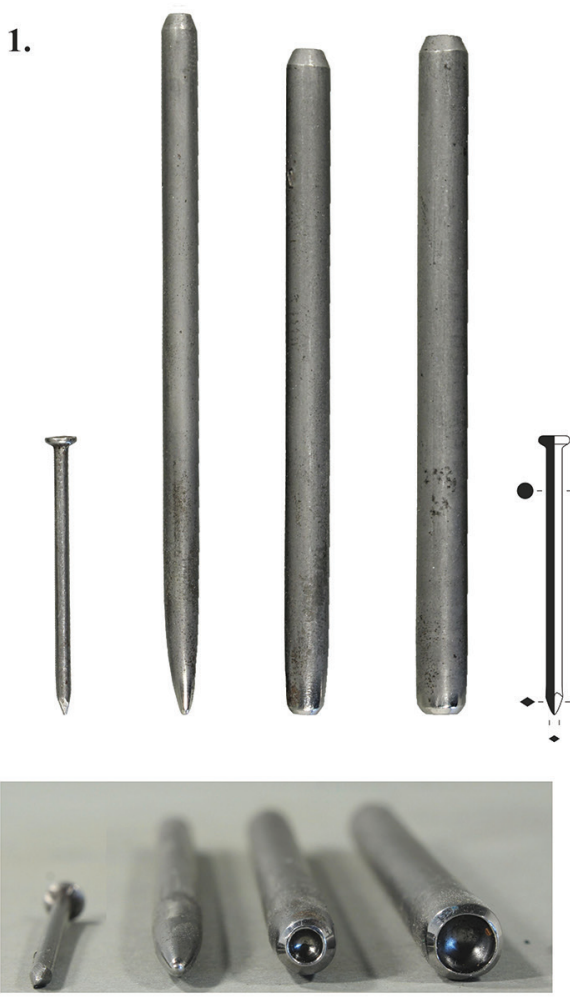

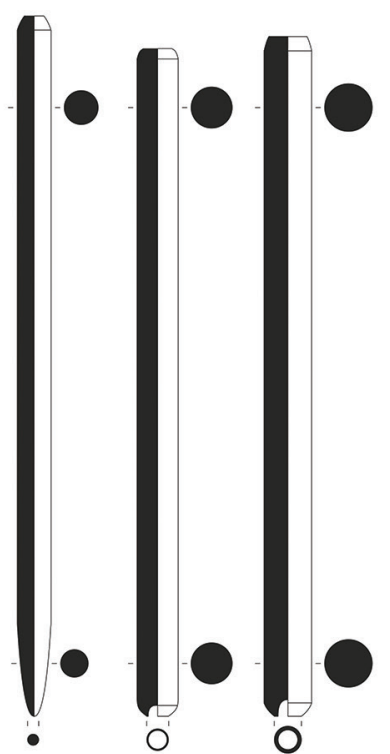

2.

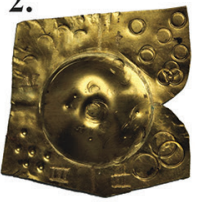

Figure 9. 1: Photo and drawing of the punches used in the experiment (from left to right): nail with rhombic profiled tip; stippling punch number 33; ring punch numbers 27 and 31. 2: The processed brass sample. Photographs by D. Schwarcz, R. Göttlich; edited by D. Schwarcz. 
Table 1. Summary of the experimental metalworking processes conducted on sample 1 and 2.

\begin{tabular}{llllcc}
\hline & Processed area & Surface & Applied tool & Operating angle & Figure number \\
\hline Sample 1 & & Flat & Nail & $90^{\circ}$ & 10. \\
\hline \multirow{3}{*}{ Sample 2 } & Field 1 & Flat & Ring-punch, no. 27 & $90^{\circ}$ & 11. \\
& Field 2 & Flat & Ring-punch, no. 31 & $90^{\circ}$ & 12. \\
& Field 3 & Flat & Punch, no. 33 & $90^{\circ}$ & 12. \\
& Field 4 & Flat & Ring-punch, no. 27 & $45-60^{\circ}$ & 11. \\
& Dome & convex & Punches: no. 27, 31, 33 & $90-120^{\circ}$ & 13. \\
\hline
\end{tabular}

cut out of a brass sheet ${ }^{4}$ and flattened using a rubber mallet. A hardened steel block was placed under the sheet metal strip. Subsequently, a small nail ${ }^{5}$ (tip with rhombic profile), an ad hoc 'stippling punch' (cf. chapter 2.2) was used to create a random pattern (Figure 10) in pointillé technique. During the process, the orientation of the nail to the surface was perpendicular. Secondly, sample 2, a piece of scrap metal of adequate size, originally cut out of the same brass sheet as sample 1, was selected from our inventory. First, a dome was formed in the centre of the piece by embossing ("Formtreiben"), for which a die ("Anke") and a punch with spherical head ("Kugelpunze") was used". The remaining flat space between the edge of the metal sheet and the dome was divided into four fields. On each field, as well as on the dome, different punches held at specific angles were applied, summarized in Table 1. (cf. Figure 8.1), to create

\footnotetext{
4 The brass sheet with appropriate cold working properties (zinc content: less than $20 \%$ ) was obtained from a commercial hardware store; however, the exact alloy composition is not known.

${ }^{5}$ Measurements of the nail: L. $3.80 \mathrm{~cm}$, shaft DIA. $0.20 \mathrm{~cm}$

6 The measurements of the final piece are L. $\times$ W. $4.18 \times 4.26 \mathrm{~cm}$, THK. $0.06 \mathrm{~cm}$.
}

a random decoration, adequate for tool mark analysis. Two ring-punches (number 27, and number 31) and a punch with rounded pointed edge ("stippling punch" number 33$)^{7}$ were involved in the process. Neither of the samples was recrystallized before, during or after the metalworking.

Finally, the samples were analysed and selected punch marks were documented using a Zeiss EVO 60 XVP scanning electron microscope in the laboratory of the Vienna Institute for Archaeological Science.

\subsection{Results and interpretation}

The shape and size of the punched decorations permit several important observations: The small nail with rhombic profiled pointed tip, an improvised punching tool, left elongated plum seed-like marks with irregular contours on sample 1. Not only the contours, but also the shape, size and even the inner surface of the marks vary (Figures 10.1,3-4). Although a nail is suitable for preparing simple decorations, especially in pointillé technique, the microscopic analyses reveal that the

\footnotetext{
Measurements of the punches: number 27, L. $9.24 \mathrm{~cm}$; shaft DIA. $0.62 \mathrm{~cm}$, working edge DIA. external $0.40 \mathrm{~cm}$, internal $0.29 \mathrm{~cm}$; number 31 , L. $9.38 \mathrm{~cm}$, shaft DIA. $0.71 \mathrm{~cm}$, working edge DIA. external $0.57 \mathrm{~cm}$, internal $0.50 \mathrm{~cm}$; and number 33, L. $9.66 \mathrm{~cm}$, shaft DIA. $0.50 \mathrm{~cm}$
}
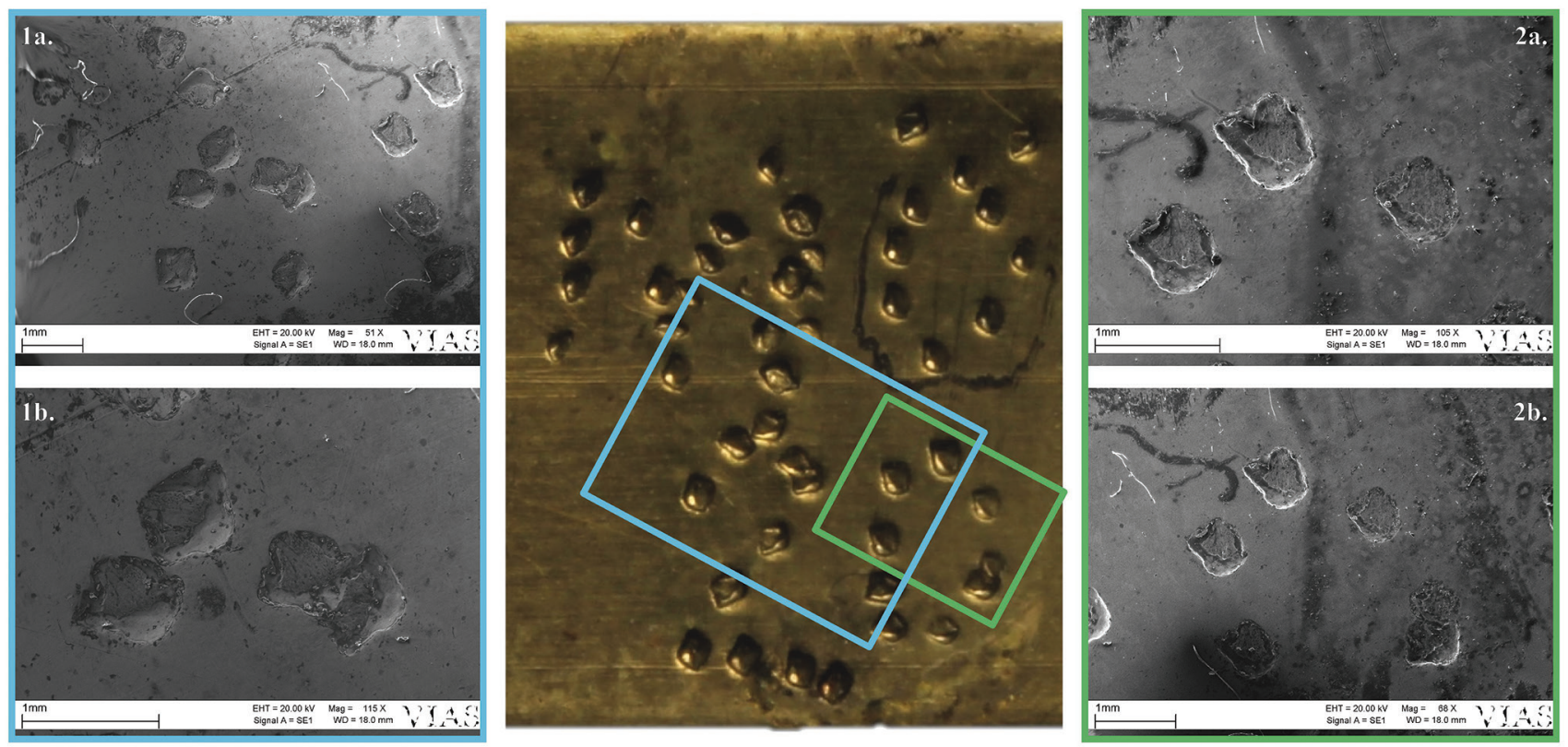

Figure 10. Macroscopic photo of a metal strip decorated by punching with a rhombic-headed nail and the corresponding SEM-photos. Photographs by D. Schwarcz, SEM-photographs by B. Bühler, D. Schwarcz; edited by D. Schwarcz. 

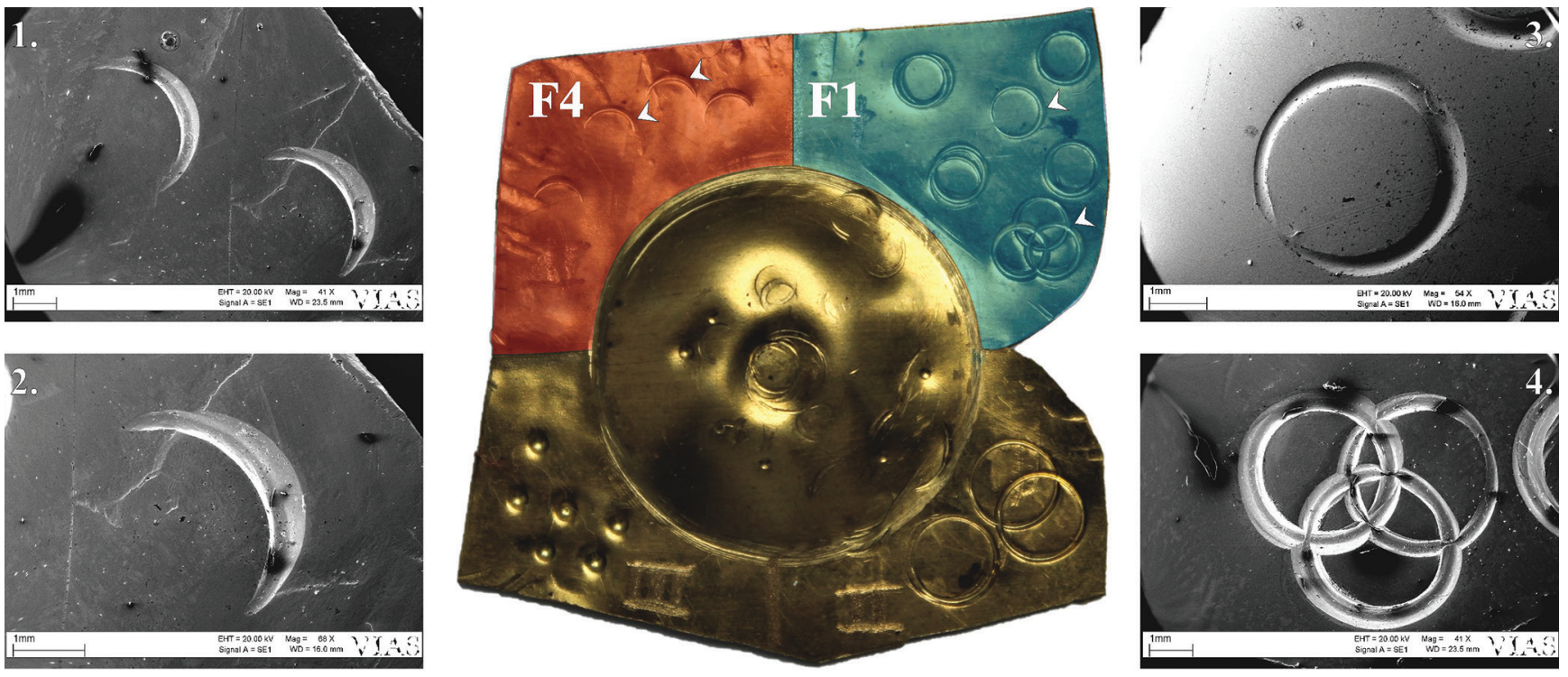

Figure 11. Field 1 and 4 on the experimental sample and the corresponding SEM-photos. 1-2: Field 1; 3-4: Field 4 (white arrows mark the specific photographed punched motives). Photographs by D. Schwarcz, SEM-photographs by B. Bühler, D. Schwarcz; edited by D. Schwarcz.
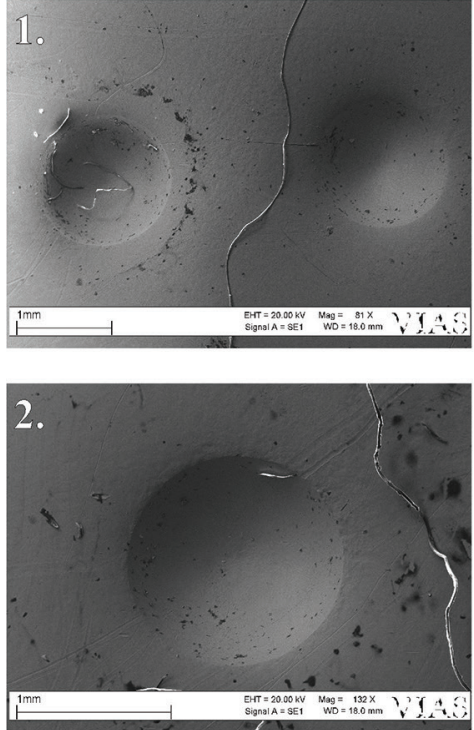
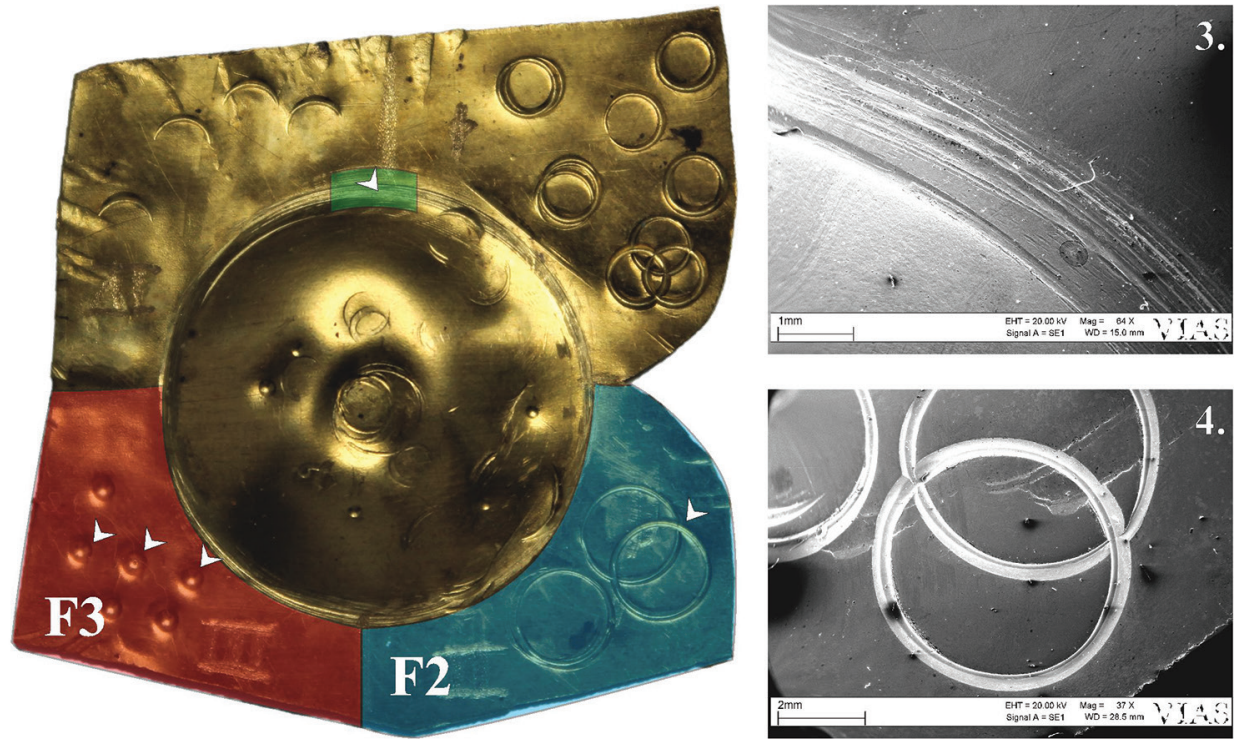

Figure 12. Field 2 and 3 on the experimental sample and the corresponding SEM-photos. 1-2: Field 3-4: Field 2 (white arrows mark the specific photographed punched motives). 3: Tool marks deriving from die-forming in the area marked with green. Photographs by D. Schwarcz, SEM-Photographs by B. Bühler, D. Schwarcz; edited by D. Schwarcz.

patterns were created by a tool with a rudimentary working edge. This statement is supported by the uneven surface of the recesses, in contrast to the smooth concave impressions made by proper punches (Figure 12.2). Most of the punched dots and rings on sample 2 do not show irregularities in their shape, but slight differences in their size are apparent. Although, the base ring-motive remains constant, the rim (determined by the side of the tool's head) is in several cases wider or narrower depending on how deep the punch entered the surface ( $c f$. Figure 11.4, ring on top right).

Regarding our other research question concerning the operating angle of the punches, besides individual pressed patterns in field 1 and 4, the tool marks on the dome show the greatest diversity. On the reference field number 4, where the ring-punch number 27 was held at 45-60 degrees, regular crescent-shaped motives can be seen (Figures 11.1-2). Without knowing the exact tools and technique carried out, one might conclude, based exclusively on the length of the motives, that the punched decoration was executed by a ringtool and not with a punch having a crescent-shaped head. One peculiar ring-decoration deserves our attention from the field 1 (Figure 11.3), where the same tool (number 27) was applied. Even though the intention was to hold the punch perpendicular to the surface, presumably, an error occurred, resulting in a slightly different punching angle. This fault in the working process must have also been supported by the 

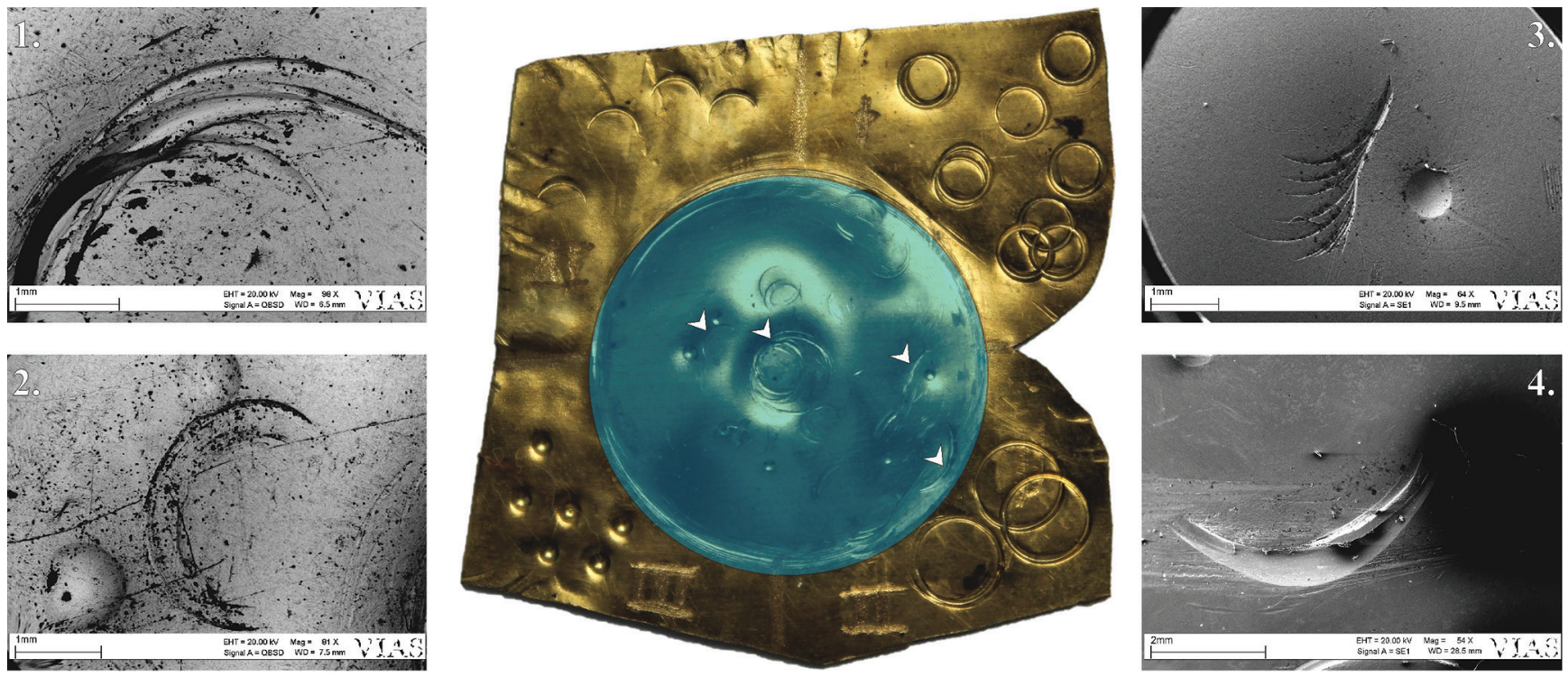

Figure 13. The domed field on the experimental sample and the corresponding scanning electron microscopic photos (white arrows mark the specific photographed punched motives). Photographs by D. Schwarcz, SEM-photographs by B. Bühler, D. Schwarcz; edited by D. Schwarcz.
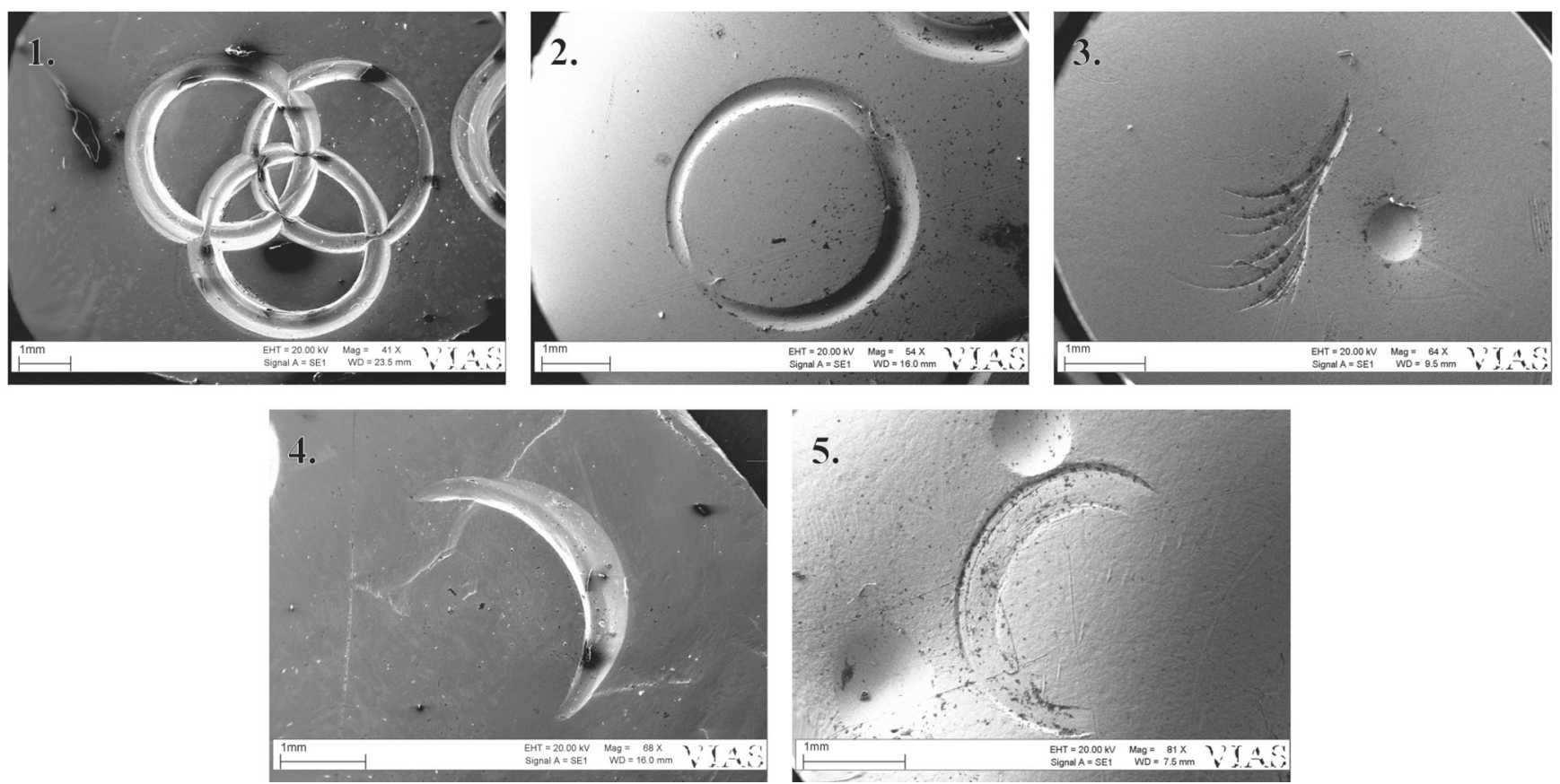

Figure 14. SEM-photos of dissimilar punch marks derived from the same tool (ring-punch number 27). SEM-photographs by B. Bühler and D. Schwarcz; edited by D. Schwarcz.

hardness of the unannealed sheet ${ }^{8}$ resulting in an interrupted circular pattern. On the dome, a slightly irregular crescentshaped punch prepared by ring tool number 27 (Figures 13.4 and 11.2) and other curved semi-circular lines made by the latter tool (Figure 13.3) as well as number 31 (Figure 13.1) are located. The striking differences of the patterns is due to

\footnotetext{
${ }^{8}$ Another indication of the metal sheet's rigidity is apparent in the shallow concentric lines at the conjunction point of the dome and the flat part of sample 2 (Figure 5.2). These marks are the imprints of the die's edge from shaping the dome by embossing. In the case of a work piece regularly recrystallized during processing, such tool marks are less likely to appear.
}

the three-dimensional surface geometry and the variations of the punching angle $\left(90-120^{\circ}\right)$. Another peculiar motive, compiled by ring-tool number 27 , can be found on the dome, consisting of two concentric semi-circular lines (Figure 13.2). This must have formed due to the combination of several factors: the non-annealed material, the lack of proper support for the dome and the convex surface. All these prevented the punch from entering deeper into the metal surface; hence, it left only the outlines of the working edges behind.

If the punched decorations made by the same tool (ring-punch number 27) are compared, a series of patterns 
with different features can be identified. Regular ring (Figure 14.1), interrupted circle (Figure 14.2), semi-circular lines (Figure 14.3), crescent-shaped motive (Figure 14.4) and concentric semi-circular lines (Figure 14.5) are the patterns made by the very same tool. The operating angle of the punch appears to be the main reason for the change (or distortion) in the basic ring motive.

\section{Conclusion}

The technological choices made in the production process of a particular gold or silver object can provide us with valuable information not only on the level of metalworking skill, but also on the background and affiliations of the goldsmith who created this particular product. The aim of this paper is to present the methodological issues and potential of comparative tool mark studies, using a case study on high-quality sheet gold metalwork from the Middle and Late Avar Period $\left(7^{\text {th }}-8^{\text {th }}\right.$ centuries AD). The process of the comparative interpretation of tool marks can take place at different levels. On the most specific level, this process can involve the identification of individual tools, followed by the classification of specific types of tool, by technical preferences and idiosyncrasies of individual metalworkers and progressing to the higher-level aspects, such as the identification of metalworking traditions characteristic of individual workshops, as well as to larger-scale, local or regional metalworking traditions. In some cases, comparative tool mark studies permit the identification of artefacts produced by the same craftsperson: The best way of verifying such a hypothesis is to demonstrate the use of identical tools in the production process of two or more particular metal products. The pre-requisite for this, however, is the identification of individual tools on the metal objects in question. Characteristic irregularities on the surface of a tool's working-edge can facilitate the identification of specific, individual metalworking tools. In the absence of such typical faults, exact measurements of the dimensions of the tool-marks may assist in identifying a specific tool. However, when interpreting the results of comparative tool mark studies, several aspects are relevant, including processes of wear and variations regarding tool orientation. In this context, experimental archaeology may contribute to the interpretation of tool marks, but further research is required: for example, regarding questions of individual variation.

In the current paper, we demonstrated how "basic" and "comparative tool mark studies" can reveal far-reaching cultural connections through the analyses of technological details. The specific choices the goldsmith made in the production of non-ferrous metal objects provide us with valuable information at various levels: ranging from the metalworking skill (through the background and affiliation) of the craftsperson to micro- and macro-regional metalworking traditions, which further highlight possible technological transmissions between distant realms.
The group of gold vessels with "Stäbchenrankenzier" from the "Nagyszentmiklós Treasure" and the gold belt ornaments from the so-called "Brestovac Hoard" are both outstanding examples of sheet-gold metalwork from the Middle and Late Avar Period ( $7^{\text {th }}-8^{\text {th }}$ centuries AD). Although qualitative differences could be established between the two groups of objects, the exceptionally executed repoussé technique binds these high-quality gold items together under the metalworking traditions of "Italo-Byzantine" goldsmith workshops. Furthermore, other decorative techniques, like "stippling" and the ring-shaped punch-marks used as background ornaments, also point towards the important role of the Mediterranean region in transmitting metalworking techniques, including motifs and artistic conventions, to the Avar realm in the Carpathian Basin.

Concerning the decoration technique of punching, fundamental methodological questions were addressed. Despite the limited number of punching tools used in this experiment, the studied tool marks enriched our perspectives on several aspects of this decorative technique. It was successfully illustrated how different factors could have an effect on the shape and size of the punched decorations. In addition, the comparison of tool marks derived from the same tool increases awareness of the methodological issues associated with the identification of tool marks and their technological interpretation. The current study, involving comparative tool mark analyses combined with experimental archaeology, was a preliminary attempt to expand our knowledge on the metalworking process of punching. Given the highly informative results, we aim to pursue wellgrounded research in the future, including experimental methods on other metalworking techniques as well.

\section{References}

ARMBRUSTER, B.R., 2000. Goldschmiedekunst und Bronzetechnik. Studien zum Metallhandwerk der Atlantischen Bronzezeit auf der Iberischen Halbinsel. Montagnac.

BÁLINT, C., 2010. Der Schatz von Nagyszentmiklós. Varia Archaeologica Hungarica XVIb, Budapest: Ungarische Akademie der Wissenschaften.

BÜHLER, B., 1998-1999. Untersuchungen zu Guß, Oberflächenbearbeitung und Vergoldung an frühmittelalterlichen Bunt- und Edelmetallgegenständen. Archaeologia Austriaca, 82-83, pp. 429-478.

BÜHLER, B., 2014. Der „Schatz" von Brestovac, Kroatien. Seine kulturellen Beziehungen und technologischen Aspekte. Monographien des Römisch-Germanischen Zentralmuseums Mainz, 85, Mainz.

BÜHLER, B. and FREIBERGER, V., 2018. Die Ergebnisse der goldschmiedetechnischen und chemischen Untersuchungen. In: F. Daim ed. Der Goldschatz von Sânnicolau Mare (ungarisch: Nagyszentmiklós). Monographien des Römisch-Germanischen Zentralmuseums Mainz, 142, Teil 1, Mainz, pp. 23-201.

BREPOHL, E., 1978. Theorie und Praxis des Goldschmieds. $5^{\text {th }}$ ed. Leipzig. DAL, L., 2017. Scientific analyses of Sösdala objects. In: C. Fabech, and U. Näsman eds. The Sösdala horsemen - and the equestrian elite of fifth century Europe. Jutland Archaeological Publications, 99, Aarhus: Aarhus University Press, pp. 131-152.

LARSEN, B., 1987. SEM-Identification and Documentation of Tool Marks and Surface Textures on the Gundestrup Cauldron. In: J. Black, ed. Recent Advances in the Conservation and Analysis of Artifacts. London: Londons University of London, Institute of Archaeology, pp. 393-408. MORTIMER, C., STONEY, M., 1997. A Methodology of Punchmark 
IANSA $2021 \quad \bullet \quad X I I / 1 \quad \bullet \quad 69-81$ Birgit Bühler, Dávid Zsolt Schwarcz: The Comparative Study of Tool Marks on Non-Ferrous Metalwork from Archaeological Contexts: Methodological Considerations,

Analysis Using Electron Microscopy. In: A. Sinclair, E. Slater, J. Gowlett, eds. Archaeological Sciences 1995. Proceedings of a conference on the application of scientific techniques to the study of archaeology. Oxbow Monograph 64. Oxford (reprint 2017), pp. 119-122.

RICCI, M., 2012. Rome-Byzantium Affinity and Difference in the Production of Luxury Goods. In: B. Böhlendorf, B. Arslan and A. Ricci, eds.
Byzantine Small Finds in Archaeological Contexts. Byzas, 15, Istambul: Deutsches Archäologisches Institut, Istanbul, pp. 1-16.

SCOTT, D.S., 1991. Metallography and Microstructure of Ancient and Historic Metals. Singapore: Getty Conservation Institute, J. Paul Getty Museum. 
